\title{
Analiza skuteczności aplikowania o środki finansowe z programu SAPARD w latach 2002-2004
}

\section{Wstęp}

Program SAPARD (ang. Support for Accession Measures for Agriculture and Rural Development) został utworzony w celu dostosowania krajów kandydujacych do acquis communataire w zakresie rolnictwa i rozwoju wsi [Rozporządzenie WE 1268/99]. SAPARD jest programem o charakterze strukturalnym, gdyż wsparcie Wspólnoty jest realizowane w formie wieloletnich programów przygotowanych zgodnie $z$ wytycznymi i zasadami programów operacyjnych stosowanych $\mathrm{w}$ ramach polityki strukturalnej [Rozporządzenie WE 2222/2000]. Przypuszczać więc można, iż doświadczenie zdobyte przez beneficjentów programu SAPARD powinno procentować w przyszłości przy korzystaniu $\mathrm{z}$ funduszy strukturalnych Unii Europejskiej. W związku z powyższym zasadne wydaje się być porównanie wykorzystania tego programu w różnych regionach kraju. Autorzy skoncentrowali uwage na województwie podlaskim, ze względu na jego dość duże zapóźnienia w rozwoju infrastruktury oraz typowo rolniczy charakter.

\section{Wdrażanie programu SAPARD w Polsce}

Program Operacyjny SAPARD dla Polski został przygotowany przez Ministerstwo Rolnictwa i Rozwoju Wsi na podstawie dwóch podstawowych dokumentów strategicznych ${ }^{1}$ :

1) Narodowy program przygotowania do członkostwa,

${ }^{1}$ Zaczerpnięto $\mathrm{z}$ www.arimr.gov.pl, 15.06.2004 r. 
2) Spójna polityka strukturalna rozwoju obszarów wiejskich i rolnictwa z uwzględnieniem ustaleń Paktu dla wsi.

Rozpoczęcie prógramu SAPARD w Polsce i w pozostałych krajach kandydujących do członkostwa zostało uwarunkowane zrealizowaniem wielu działań zarówno przez Komisję Europejska, jak i Polskę, określonych w regulacjach stanowiących podstawę do realizacji programu i obejmujących:

a) zatwierdzenie przez Komisję Europejską Programu Rozwoju Obszarów Wiejskich - Programu Operacyjnego SAPARD dla Polski,

b) podpisanie wieloletniej umowy finansowej,

c) podpisanie rocznej umowy finansowej,

d) podjęcie przez Komisję Europejską decyzji o przekazaniu Polsce zarządzania pomocą (potwierdzenie akredytacji krajowej).

Polska przedłożyła Program Operacyjny Komisji Europejskiej 28 grudnia 1999 r. Program został zatwierdzony po bilateralnych konsultacjach decyzja Komisji. Europejskiej 18 października 2000 r. Oficjalny dokument potwierdzający przekazanie Polsce zarządzaniem programem SAPARD został opublikowany w Dzienniku Urzędowym Wsspólnot Europejskich z dnia 2 lipca 2002 r. [Decyzja WE 2002/593/EC] i wtedy też zgodnie z decyzją Komisji Europejskiej zostały zatwierdzone do wdrażania działania objęte akredytacją. Wnioski należało składać w oddziałach regionalnych Agencji Restrukturyzacji i Modernizacji Rolnictwa, która została jednostką zarządzającą programu SAPARD [Rozporządzenie RM z 14.05.2002 r.]. Terminy składania wniosków w ramach poszczególnych działań były następujące:

Działanie 1. Poprawa przetwórstwa i marketingu artykułów rolnych i rybnych:

- I tura - od 17 lipca do 16 października 2002 r.,

- II tura - od 6 stycznia do 7 lutego 2003 r.,

- III tura - od 26 maja do 27 czerwca 2003 r.,

- IV tura - od 30 lipca do 29 września 2003 r.,

- V tura - od 29 października do 1 grudnia 2003 r.,

- VI tura - od 2 grudnia 2003 r. do 2 stycznia 2004 r.,

- VII tura - od 5 stycznia do 5 lutego $2004 \mathrm{r}$.

Działanie 2. Inwestycje $\mathrm{w}$ gospodarstwach rolnych: od 17 lipca 2002 r. do 20 lutego $2004 \mathrm{r}$.

Działanie 3. Rozwój i poprawa infrastruktury obszarów wiejskich:

- I tura - od 17 lipca do 16 września 2002 r.,

- II tura - od 30 lipca do 15 września 2003 r.

Działanie 4. Różnicowanie działalności gospodarczej na obszarach wiejskich:

- I tura - od 3 grudnia do 22 grudnia 2003 r.,

- II tura - od 23 grudnia 2003 r. do 12 stycznia 2004 r. (w schematach 4. 1 i 4.2 została przedłużona do 26 stycznia 2004 r.). 


\section{Wnioski złożone w ramach programu SAPARD}

Liczbę wniosków złożonych w poszczególnych oddziałach przedstawia tabela 1. Dane w niej zawarte dotyczą okresu od momentu uruchomienia programu SAPARD do dnia 30.06.2004 r.

Z tabeli 1 wynika, iż łącznie w badanym okresie zostało złożonych 31097 wniosków, w tym: w Działaniu 1 - 1778, w Działaniu 2 - 15 586, w Działaniu 3 - 6230, w Działaniu 4 - 7503. Najwięcej wniosków złożono w województwie mazowieckim - łącznie 5138 w czterech działaniach (16,52\% ogółu). Najmniej wniosków złożono w województwie opolskim - 654, co stanowiło $2,1 \% \mathrm{w}$ skali całego kraju. W województwie podlaskim w badanym okresie złożono 1468 wniosków (4,72\%) (rys. 1).

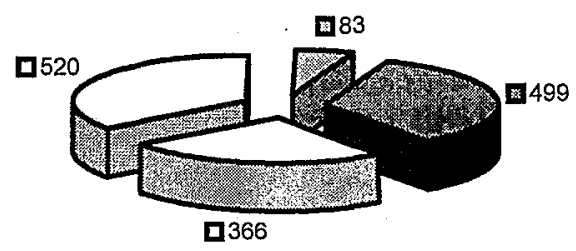

\section{回1}

\section{Rysunek 1}

Liczba złożonych wniosków w województwie podlaskim w poszczególnych działaniach Źródło: Opracowanie własne na podstawie danych empirycznych.

$Z$ rysunku 1 wynika, iż największa liczba wniosków została złożona w ramach działania 4 (520), co może napawać optymizmem, gdyż działanie to wydatnie przyczynia się do rozwoju małej przedsiębiorczości, która stanowi o sile całej gospodarki.

\section{Wnioski zarejestrowane w ramach programu SAPARD}

Wnioski złożone w oddziałach ARiMR przed zarejestrowaniem przechodzą wstępną weryfikację. Na tym etapie są sprawdzane kompletność wniosku i uprawnienia beneficjenta do ubiegania się o pomoc. Tabela 2 przedstawia liczbę wniosków zarejestrowanych w poszczególnych oddziałach ARiMR. 
Tabela 1

Liczba złożonych wniosków o pomoc finansową z programu SAPARD w oddziałach ARiMR

\begin{tabular}{|c|c|c|c|c|c|c|c|c|c|c|c|c|c|c|c|c|c|}
\hline Dzialanie/schemat/komponent & 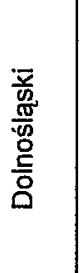 & 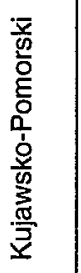 & $\begin{array}{l}\frac{\overline{0}}{00} \\
\frac{0}{3}\end{array}$ & 竞 & 亲 & 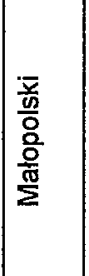 & 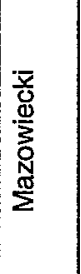 & $\begin{array}{l}\frac{\text { 홍 }}{0} \\
\text { 응 }\end{array}$ & 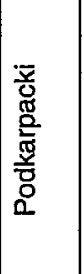 & $\begin{array}{l}\frac{\bar{y}}{D} \\
\frac{\mathbb{O}}{\overline{8}} \\
0\end{array}$ & 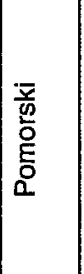 & $\frac{\bar{s}}{\frac{5}{0}}$ & 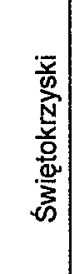 & 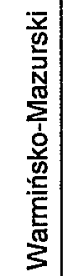 & 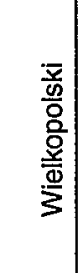 & 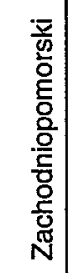 & 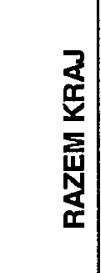 \\
\hline 1 & 2 & 3 & 4 & 5 & 6 & 7 & 8 & 9 & 10 & 11 & 12 & 13 & 14 & 15 & 16 & 17 & 18 \\
\hline $\begin{array}{l}\text { Poprawa przetwórstwa i marketingu } \\
\text { artykułów rolnych i rybnych }\end{array}$ & 77 & 110 & 100 & 66 & 141 & 116 & 216 & 44 & 65 & 83 & 132 & 132 & 45 & 101 & 278 & 72 & 1778 \\
\hline $\begin{array}{l}\text { 1.1. Wsparcie restrukturyzacji przetwór- } \\
\text { stwa i poprawa marketingu artykułów } \\
\text { pochodzenia zwierzęcego }\end{array}$ & 63 & 81 & 64 & 62 & 113 & 91 & 159 & 39 & 48 & 73 & 116 & 114 & 30 & 90 & 230 & 56 & 1429 \\
\hline 1.1a Sektor mleczarski & 16 & 33 & 29 & 14 & 33 & 18 & 61 & 14 & 10 & 30 & 10 & 18 & 9 & 35 & 48 & 7 & 385 \\
\hline 1.1b Sektor mięsny & 42 & 43 & 35 & 48 & 79 & 70 & 95 & 25 & 36 & 39 & 62 & 90 & 19 & 49 & 173 & 24 & 929 \\
\hline 1.1c Sektor rybny & 5 & 5 & & & 1 & 3 & 3 & & 2 & 4 & 44 & 6 & 2 & 6 & 9 & 25 & 115 \\
\hline $\begin{array}{l}\text { 1.2. Wsparcie restrukturyzacji przetwór- } \\
\text { stwa i poprawa marketingu owoców } \\
\text { i warzyw }\end{array}$ & 14 & 29 & 36 & 4 & 28 & 25 & 57 & 5 & 17 & 10 & 16 & 18 & 15 & 11 & 48 & 16 & 349 \\
\hline Inwestycje w gospodarstwach rolnych & 389 & 1234 & 1678 & 186 & 1077 & 1028 & 3718 & 276 & 272 & 499 & 765 & 276 & 1495 & 433 & 1997 & 263 & 15586 \\
\hline 2.1. Restrukturyzacja produkcji mleka & 12 & 113 & 76 & 9 & 121 & 7 & 193 & 31 & 27 & 306 & 23 & 19 & 38 & 48 & 145 & 10 & 1178 \\
\hline $\begin{array}{l}\text { 2.2. Modernizacja gospodarstw specjali- } \\
\text { zujących się w produkcji zwierzą̧ rzeź- } \\
\text { nych }\end{array}$ & 22 & 183 & 45 & 20 & 61 & 36 & 58 & 34 & 28 & 39 & 62 & 59 & 28 & 50 & 294 & 30 & 1049 \\
\hline $\begin{array}{l}\text { 2.2.1. Modernizacja gospodarstw specja- } \\
\text { lizujących się w produkcji bydła mięsnego }\end{array}$ & 2 & 3 & 2 & 7 & 3 & 3 & 1 & & 1 & 10 & 3 & 1 & 7 & $1)$ & 4 & 20 & 68 \\
\hline 2.2.2. Odbudowa produkcji owczarskiej & & 1 & 5 & 1 & 4 & 6 & 6 & 1 & 3 & 1 & 5 & 3 & 3 & & 4 & 1 & 44 \\
\hline $\begin{array}{l}\text { 2.2.3. Modernizacja produkcji trzody } \\
\text { chlewnej lub drobiu }\end{array}$ & 20 & 179 & 38 & 12 & 54 & 27 & 51 & 33 & 24 & 28 & 54 & 55 & 18 & 49 & 286 & 9 & 937 \\
\hline
\end{tabular}




\begin{tabular}{|c|c|c|c|c|c|c|c|c|c|c|c|c|c|c|c|c|c|}
\hline $\begin{array}{l}\text { 2.3. Zwiększenie różnorodności produkcji } \\
\text { gospodarstw rolnych }\end{array}$ & 355 & 938 & 1557 & 157 & 895 & 985 & 3467 & 211 & 217 & 154 & 680 & 198 & 1429 & 335 & 1558 & 223 & 13359 \\
\hline $\begin{array}{l}\text { Rozwój i poprawa infrastruktury obszarów } \\
\text { wiejskich }\end{array}$ & 324 & 376 & 465 & 182 & 400 & 557 & 650 & 143 & 518 & 366 & 337 & 384 & 360 & 260 & 699 & 209 & 6230 \\
\hline $\begin{array}{l}\text { 3.1. Zaopatrzenie gospodarstw wiejskich } \\
\text { w wodę wraz z uzdatnieniem }\end{array}$ & 74 & 67 & 91 & 54 & 80 & 82 & 164 & 34 & 47 & 83 & 87 & 52 & 87 & 101 & 110 & 69 & 1282 \\
\hline $\begin{array}{l}\text { 3.2. Odprowadzenie i oczyszczanie } \\
\text { ścieków komunalnych }\end{array}$ & 101 & 126 & 106 & 55 & 70 & 195 & 125 & 54 & 188 & 67 & 128 & 143 & 81 & 87 & 269 & 74 & 1869 \\
\hline 3.3. Gospodarka odpadami stałymi & 3 & 5 & 3 & 1 & 1 & 3 & 2 & 1 & 5 & 3 & 3 & 2 & 1 & 3 & 9 & & 45 \\
\hline $\begin{array}{l}\text { 3.4. Drogi gminne i powiatowe na obsza- } \\
\text { rach wiejskich }\end{array}$ & 142 & 178 & 262 & 67 & 248 & 267 & 359 & 52 & 277 & 203 & 118 & 185 & 191 & 69 & 309 & 62 & 2989 \\
\hline 3.5. Zaopatrzenie w energię & 4 & & 3 & 5 & 1 & 10 & & 2 & 1 & 10 & 1 & 2 & & & 2 & 4 & 45 \\
\hline $\begin{array}{l}\text { Różnicowanie działalności gospodarczej } \\
\text { na obszarach wiejskich }\end{array}$ & 463 & 328 & 475 & 235 & 440 & 785 & 554 & 191 & 676 & 520 & 513 & 473 & 350 & 485 & 726 & 289 & 7503 \\
\hline $\begin{array}{l}\text { 4.1. Tworzenie źródeł dodatkowego } \\
\text { dochodu na obszarach wiejskich }\end{array}$ & 169 & 98 & 184 & 84 & 126 & 217 & 169 & 62 & 252 & 347 & 207 & 122 & 129 & 233 & 182 & 112 & 2693 \\
\hline $\begin{array}{l}\text { 4.2. Tworzenie miejsc pracy na obsza- } \\
\text { rach wiejskich }\end{array}$ & 259 & 187 & 237 & 129 & 278 & 437 & 368 & 108 & 359 & 140 & 257 & 316 & 190 & 222 & 499 & 146 & 4132 \\
\hline $\begin{array}{l}\text { 4.3 Publiczna infrastruktura turystyczna } \\
\text { na obszarach wiejskich }\end{array}$ & 35 & 43 & 54 & 22 & 36 & 131 & 17 & 21 & 65 & 33 & 49 & 35 & 31 & 30 & 45 & 31 & 678 \\
\hline SUMA & 1253 & 2048 & 2718 & 669 & 2058 & 2486 & 5138 & 654 & 1531 & 1468 & 1747 & 1265 & 2250 & 1279 & 3700 & 833 & 31097 \\
\hline
\end{tabular}

Źródlo: www.arimr.gov.pl, dane $z$ dnia 10.11.2004 r. 
Tabela 2

Liczba zarejestrowanych wniosków o pomoc finansową z programu SAPARD w oddziałach AR i MR

\begin{tabular}{|c|c|c|c|c|c|c|c|c|c|c|c|c|c|c|c|c|c|}
\hline Działanie/schemat/komponent & $\begin{array}{l}\text { 总 } \\
\frac{\sigma}{00} \\
\text { 등 } \\
0\end{array}$ & 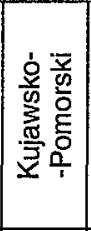 & $\begin{array}{l}\frac{\bar{x}}{0} \\
\frac{0}{3}\end{array}$ & 音 & 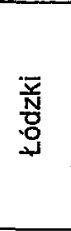 & $\begin{array}{l}\frac{\bar{x}}{0} \\
\frac{0}{0} \\
\frac{0}{0}\end{array}$ & $\begin{array}{l}\text { 정 } \\
\text { 产 } \\
\text { N } \\
\text { ख }\end{array}$ & $\frac{\bar{x}}{\frac{5}{0}}$ & 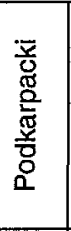 & $\begin{array}{l}\frac{\bar{y}}{6} \\
\frac{0}{\bar{O}} \\
8\end{array}$ & 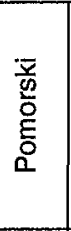 & $\frac{\bar{y}}{\frac{\bar{w}}{w}}$ & 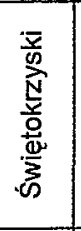 & 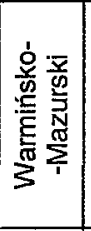 & $\begin{array}{l}\frac{\bar{x}}{0} \\
\frac{0}{\circ} \\
\frac{0}{0} \\
\frac{8}{\Phi} \\
\frac{9}{3}\end{array}$ & 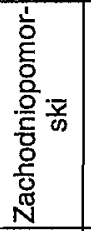 & 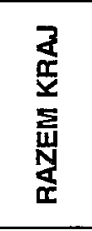 \\
\hline 1 & 2 & 3 & 4 & 5 & 6 & 7 & 8 & 9 & 10 & 11 & 12 & 13 & 14 & 15 & 16 & 17 & 18 \\
\hline $\begin{array}{l}\text { Poprawa przetwórstwa i marketingu } \\
\text { artykułów rolnych i rybnych }\end{array}$ & 50 & 99 & 88 & 47 & 116 & 103 & 172 & 38 & 61 & 70 & 110 & 121 & 43 & 90 & 249 & 57 & 1514 \\
\hline $\begin{array}{l}\text { 1.1. Wsparcie restrukturyzacji przetwór- } \\
\text { stwa i poprawa marketingu artykułów } \\
\text { pochodzenia zwierzęcego }\end{array}$ & 41 & 73 & 59 & 45 & 97 & 82 & 131 & 33 & 45 & 62 & 97 & 104 & 29 & 79 & 208 & 46 & 1231 \\
\hline 1.1.a Sektor mleczarski & 10 & 30 & 27 & 13 & 28 & 17 & 53 & 13 & 10 & 30 & 10 & 18 & 9 & 34 & 46 & 6 & 354 \\
\hline 1.1.b Sektor miesny & 28 & 38 & 32 & 32 & 68 & 63 & 75 & 20 & 33 & 28 & 50 & 82 & 19 & 40 & 153 & 19 & 780 \\
\hline 1.1.c Sektor rybny & 3 & 5 & & & 1 & 2 & 3 & & 2 & 4 & 37 & 4 & 1 & 5 & 9 & 21 & 97 \\
\hline $\begin{array}{l}\text { 1.2. Wsparcie restrukturyzacji przetwór- } \\
\text { stwa i poprawa marketingu owoców } \\
\text { i warzyw }\end{array}$ & 9 & 26 & 29 & 2 & 19 & 21 & 41 & 5 & 16 & 8 & 13 & 17 & 14 & 11 & 41 & 11 & 283 \\
\hline Inwestycje w gospodarstwach rolnych & 308 & 1189 & 1579 & 164 & 983 & 985 & 3473 & 239 & 259 & 476 & 700 & 261 & 1431 & 401 & 1890 & 207 & 14545 \\
\hline 2.1. Restrukturyzacja produkcji mleka & 10 & 108 & 72 & 9 & 109 & 6 & 176 & 31 & 26 & 288 & 19 & 17 & 38 & 44 & 138 & 9 & 1100 \\
\hline $\begin{array}{l}\text { 2.2. Modernizacja gospodarstw specjali- } \\
\text { zujących się w produkcji zwierząt rzeż- } \\
\text { nych }\end{array}$ & 16 & 172 & 39 & 15 & 52 & 34 & 49 & 29 & 24 & 36 & 59 & 55 & 27 & 45 & 277 & 17 & 946 \\
\hline $\begin{array}{l}\text { 2.2.1. Modemizacja gospodarstw specjali- } \\
\text { zujących sie w produkcji bydła mięsnego }\end{array}$ & 1 & 2 & 1 & 7 & 2 & 3 & $1)$ & & & 10 & 2 & & 7 & 1 & 4 & 11 & 52 \\
\hline 2.2.2. Odbudowa produkcji owczarskiej & & 1 & 4 & & 4 & 6 & 1 . & & 3 & 1 & 5 & 3 & 3 & & 4 & & 35 \\
\hline $\begin{array}{l}\text { 2.2.3. Modemizacja produkcji trzody } \\
\text { chlewnej i drobiu }\end{array}$ & 15 & 169 & 34 & 8 & 46 & 25 & 47 & 29 & 21 & 25 & 52 & 52 & 17 & 44 & 269 & 6. & 859 \\
\hline $\begin{array}{l}\text { 2.3. Zwiększenie różnorodności produkcji } \\
\text { gospodarstw rolnych }\end{array}$ & 282 & 909 & 1468 & 140 & 822 & 945 & 3248 & 179 & 209 & 152 & 622 & 189 & 1366 & 312 & 1475 & 181 & 12499 \\
\hline $\begin{array}{l}\text { Rozwój i poprawa infrastruktury obsza- } \\
\text { rów wiejskich }\end{array}$ & 276 & 366 & 447 & 174 & 379 & 516 & 601 & 135 & 510 & 360 & 327 & 379 & 348 & 251 & 678 & 179 & 5926 \\
\hline $\begin{array}{l}\text { 3.1. Zaopatrzenie gospodarstw wiejskich w } \\
\text { wode wraz } \mathrm{z} \text { uzdatnieniem }\end{array}$ & 67 & 63 & 88 & 53 & 75 & 76 & 153 & 32 & 46 & 82 & 86 & 51 & 85 & 100 & 107 & 60 & 1224 \\
\hline
\end{tabular}




\begin{tabular}{|c|c|c|c|c|c|c|c|c|c|c|c|c|c|c|c|c|c|}
\hline $\begin{array}{l}\text { 3.2. Odprowadzenie i oczyszczanie ście- } \\
\text { ków komunalnych }\end{array}$ & 91 & 124 & 102 & 51 & 66 & 183 & 114 & 52 & 184 & 67 & 126 & 142 & 77 & 83 & 262 & 68 & 1792 \\
\hline 3.3. Gospodarka odpadami stałymi & 3 & 4 & 2 & 1 & & 3 & 2 & 1 & 5 & 3. & 2 & 2 & 1 & 2 & 8 & & 39 \\
\hline $\begin{array}{l}\text { 3.4. Drogi gminne i powiatowe na obsza- } \\
\text { rach wiejskich }\end{array}$ & 111 & 175 & 253 & 64 & 237 & 244 & 332 & 48 & 274 & 198 & 112 & 182 & 185 & 66 & 300 & 48 & 2829 \\
\hline 3.5. Zaopatrzenie w energię & 4 & & 2 & 5 & 1 & 10 & & 2 & 1 & 10 & 1 & 2 & & & 1 & 3 & 42 \\
\hline $\begin{array}{l}\text { Różnicowanie dzialalności gospodarczej } \\
\text { na obszarach wiejskich }\end{array}$ & 246 & 243 & 365 & 146 & 334 & 691 & 359 & 158 & 594 & 365 & 357 & 405 & 291 & 366 & 636 & 189 & 5745 \\
\hline $\begin{array}{l}\text { 4.1. Tworzenie źróder dodatkowego do- } \\
\text { chodu na obszarach wiejskich }\end{array}$ & 92 & 78 & 146 & 56 & 98 & 196 & 100 & 52 & 235 & 242 & 152 & 93 & 103 & 182 & 162 & 70 & 2057 \\
\hline $\begin{array}{l}\text { 4.2. Tworzenie miejsc pracy na obszarach } \\
\text { wiejskich }\end{array}$ & 132 & 132 & 168 & 69 & 200 & 376 & 247 & 87 & 301 & 99 & 160 & 277 & 158 & 162 & 438 & 95 & 3101 \\
\hline $\begin{array}{l}\text { 4.3. Publiczna infrastruktura turystyczna na } \\
\text { obszarach wiejskich }\end{array}$ & 22 & 33 & 51 & 21 & 36 & 119 & 12 & 19 & 58 & 24 & 45 & 35 & 30 & 22 & 36 & 24 & 587 \\
\hline SUMA & 880 & 1897 & 2479 & 531 & 1812 & 2295 & 4605 & 570 & 1424 & 1271 & 1494 & 1166 & 2113 & 1108 & 3453 & 632 & 27730 \\
\hline
\end{tabular}

Źródlo: www.arimr.gov.pl, dane $z$ dnia 10.11.2004 r. 
$\mathrm{Z}$ tabeli 2 wynika, iż w skali całego kraju zarejestrowano 27730 wniosków, co stanowiło $89,17 \%$ wniosków złożonych. Oznacza to, iż 3367 wniosków zostało odrzuconych na wstępnym etapie weryfikacji. W województwie mazowieckim numer rejestrowy nadano 4605 wnioskom. Stwierdzić więc można, iż do dalszej oceny przekazano $89,63 \%$ złożonych wniosków. W województwie opolskim, do dalszej oceny przekazano $87,16 \%$ wniosków złożonych. W województwie podlaskim odrzucono 197 wniosków. Do dalszego rozpatrzenia zakwalifikowano 1271 wniosków, co stanowiło 86,58\% ogółu złożonych w tym województwie wniosków. Można zatem stwierdzić, iż województwo podlaskie znacząco nie odbiega od średniej krajowej wyznaczonej przez procentowy udział wniosków zakwalifikowanych do dalszego rozpatrzenia w ogólnej liczbie złożonych wniosków (rys. 2).

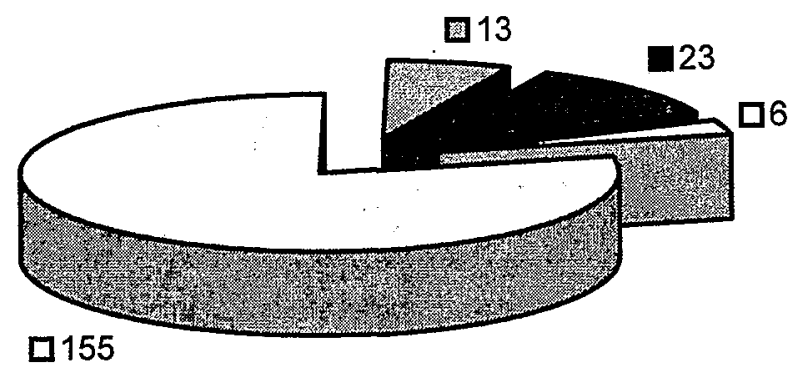

圆1 $2 \square 3 \square 4$

\section{Rysunek 2}

Liczba wniosków odrzuconych w poszczególnych działaniach w województwie podiaskim Źródło: Opracowanie własne na podstawie danych empirycznych.

$Z$ rysunku 2 wynika, iż największa liczba wniosków została odrzucona w Działaniu 4 (155), co stanowiło aż 29,8\% złożonych wniosków w tym działaniu. Najmniej wniosków odrzucono 'w Działaniu 3, (tylko 6) co stanowiło $1,63 \%$ ogólnej liczby złożonych wniosków.

\section{Wnioski z pozytywną oceną końcową}

Wnioski, które zostały zarejestrowane w systemie komputerowym, podlegają kompleksowej ocenie. Są sprawdzane ich poprawność pod względem finansowym, zgodność z celami programu, a także korzyści, jakie wygeneruje projekt po zainwestowaniu określonego kapitału. Następnie wnioskom nadawana jest gradacja. Odgórnie jest określona minimalna liczba punktów, jaką musi otrzymać projekt, aby jego realizacja była zasadna. 
Tabela 3

Liczba pozytywnie rozpatrzonych wniosków o pomoc finansową z programu SAPARD w oddziałach ARiMR

\begin{tabular}{|c|c|c|c|c|c|c|c|c|c|c|c|c|c|c|c|c|c|}
\hline Działanie/schemat/komponent & 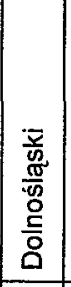 & 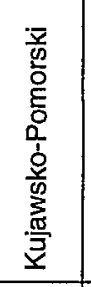 & $\begin{array}{l}\frac{\bar{x}}{0} \\
\frac{0}{\partial} \\
3\end{array}$ & $\begin{array}{l}\text { 章 } \\
\frac{3}{3} \\
\end{array}$ & 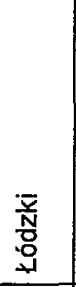 & 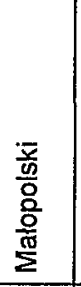 & 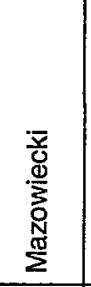 & $\frac{5}{\frac{5}{0}}$ & 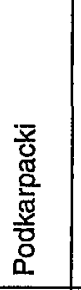 & $\begin{array}{l}\frac{\bar{y}}{0} \\
\frac{\mathbf{O}}{\mathrm{Z}} \\
8\end{array}$ & 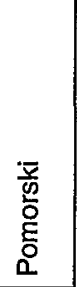 & $\frac{\bar{x}}{\frac{\bar{x}}{\sqrt[W]{n}}}$ & 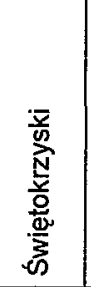 & 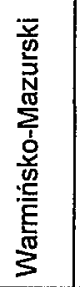 & 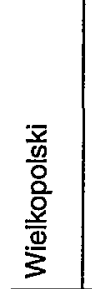 & 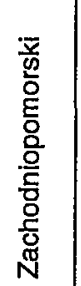 & 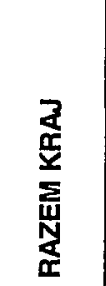 \\
\hline 1 & 2 & 3 & 4 & 5 & 6 & 7 & 8 & 9 & 10 & 11 & 12 & 13 & 14 & 15 & 16 & 17 & 18 \\
\hline $\begin{array}{l}\text { Poprawa przetwórstwa i marketingu } \\
\text { artykułów rolnych i rybnych }\end{array}$ & 48 & 93 & 81 & 41 & 100 & 92 & 147 & 32 & 54 & 65 & 91 & 111 & 42 & 80 & 228 & 48 & 1353 \\
\hline $\begin{array}{l}\text { 1.1. Wsparcie restrukturyzacji przetwórstwa } \\
\text { poprawa marketingu artykułów pochodzenie } \\
\text { zwierzęcego }\end{array}$ & 40 & 72 & 58 & 39 & 84 & 76 & 112 & 27 & 39 & 58 & 81 & 97 & 29 & 70 & 191 & 39 & 1112 \\
\hline 1.1a. Sektor mleczarski & 9 & 30 & 27 & 11 & 24 & 17 & 45 & 11 & 9 & 29 & 8 & 17 & 9 & 31 & 43 & 5 & 325 \\
\hline 1.1b. Sektor miesny & 28 & 37 & 31 & 28 & 59 & 57 & 64 & 16 & 29 & 25 & 43 & 77 & 19 & 34 & 139 & 13 & 699 \\
\hline 1.1c. Sektor rybny & 3 & 5 & & & 1 & 2 & 3 & & 1 & 4 & 30 & 3 & 1 & 5 & 9 & 21 & 88 \\
\hline $\begin{array}{l}\text { 1.2. Wsparcie restrukturyzacji przetwór- } \\
\text { stwa i poprawa marketingu owoców } \\
\text { i warzyw }\end{array}$ & 8 & 21 & 23 & 2 & 16 & 16 & 35 & 5 & 15 & 7 & 10 & 14 & 13 & 10 & 37 & 9 & 241 \\
\hline Inwestycje w gospodarstwach rolnych & 281 & 1150 & 1514 & 142 & 922 & 770 & 3030 & 211 & 232 & 449 & 677 & 231 & 1320 & 377 & 1754 & 164 & 13224 \\
\hline 2.1. Restrukturyzacja produkcji mleka & & 105 & 71 & 9 & 103 & 4 & 169 & 28 & 25 & 273 & 17 & 16 & 32 & 36 & 130 & 9 & 1036 \\
\hline $\begin{array}{l}\text { 2.2. Modernizacja gospodarstw specjali- } \\
\text { zujących się w produkcji zwierząt rzeźnych }\end{array}$ & 15 & 166 & 39 & 12 & 48 & 28 & 45 & 24 & 22 & 35 & 55 & 48 & 22 & 38 & 252 & 15 & 864 \\
\hline $\begin{array}{l}\text { 2.2.1. Modernizacja gospodarstw specjali- } \\
\text { zujacych się w produkcji bydła mięsnego }\end{array}$ & & 2 & 1 & 6 & 1 & 2 & 1 & & & 10 & 2 & & 5 & 1 & 4 & 9 & 44 \\
\hline 2.2.2. Odbudowa produkcji owczarskiej & & 1 & 4 & & 4 & 5 & & & 2 & 1 & 5 & 1 & 2 & & 2 & & 27 \\
\hline $\begin{array}{l}\text { 2.2.3. Modernizacja produkcji trzody } \\
\text { chlewnej i drobiu }\end{array}$ & 15 & 163 & 34 & 6 & 43 & 21 & 44 & 24 & 20 & 24 & 48 & 47 & 15 & 37 & 246 & 6 & 793 \\
\hline $\begin{array}{l}\text { 2.3. Zwiększenie różnorodności produkcji } \\
\text { gospodarstw rolnych }\end{array}$ & 257 & 879 & 1404 & 121 & 771 & 738 & 2816 & 159 & 185 & 141 & 605 & 167 & 1266 & 303 & 1372 & 140 & 11324 \\
\hline $\begin{array}{l}\text { Rozwój i poprawa infrastruktury obsza- } \\
\text { rów wiejskich }\end{array}$ & 226 & 351 & 435 & 167 & 354 & 492 & 557 & 123 & 499 & 352 & 287 & 368 & 340 & 220 & 662 & 152 & 5585 \\
\hline
\end{tabular}


cd. tabeli 3

\begin{tabular}{|c|c|c|c|c|c|c|c|c|c|c|c|c|c|c|c|c|c|}
\hline 1 & 2 & 3 & 4 & 5 & 6 & 7 & 8 & 9 & 10 & 11 & 12 & 13 & 14 & 15 & 16 & 17 & 18 \\
\hline $\begin{array}{l}\text { 3.1. Zaopatrzenie gospodarstw wiejskich } \\
\text { w wode wraz z uzdatnieniem }\end{array}$ & 63 & 58 & 86 & 50 & 65 & 73 & 145 & 29 & 46 & 79 & 72 & 48 & 84 & 90 & 104 & 48 & 1140 \\
\hline $\begin{array}{l}\text { 3.2. Odprowadzenie i oczyszczanie ścieków } \\
\text { komunalnych }\end{array}$ & 78 & 118 & 94 & 47 & 63 & 179 & 108 & 49 & 182 & 66 & 114 & 140 & 74 & 70 & 258 & 60 & 1700 \\
\hline 3.3. Gospodarka odpadami stałymi & 3 & 4 & 2 & 1 & & 2 & 1 & & 4 & 3 & & 2 & 1 & 1 & 8 & & 32 \\
\hline $\begin{array}{l}\text { 3.4. Drogi gminne i powiatowe na obsza- } \\
\text { rach wiejskich }\end{array}$ & 78 & 171 & 251) & 64 & 225 & 228 & 303 & 43 & 266 & 194 & 100 & 176 & 181 & 59 & 291 & 41 & 2671 \\
\hline 3.5. Zaopatrzenie w energię & 4 & & 2 & 5 & 11. & 10 & & 2 & 1 & 10 & 1. & 2 & & & 1 & 3 & 42 \\
\hline $\begin{array}{l}\text { Różnicowanie działalności gospodarczej } \\
\text { na obszarach wiejskich }\end{array}$ & 155 & 218 & 339 & 101 & 237 & 408 & 117 & 127 & 443 & 165 & 242 & 242 & 217 & 271 & 290 & 164 & 3736 \\
\hline $\begin{array}{l}\text { 4.1. Tworzenie źródel dodatkowego do- } \\
\text { chodu na obszarach wiejskich }\end{array}$ & 52 & 74 & 143 & 50 & 90 & 163 & 69 & 47 & 221 & 108 & 145 & 89 & 67 & 158 & 149 & 57 & 1682 \\
\hline $\begin{array}{l}\text { 4.2. Tworzenie miejsc pracy na obszarach } \\
\text { wiejskich }\end{array}$ & 84 & 112 & 149 & 30 & 111 & 132 & 37 & 63 & 165 & 34 & 56 & 119 & 122 & 93 & 110 & 84 & 1501 \\
\hline $\begin{array}{l}\text { 4.3. Publiczna infrastruktura turystyczna na } \\
\text { obszarach wiejskich }\end{array}$ & 19 & 32 & 47 & 21 & 36 & 113 & 11 & 17 & 57 & 23 & 41 & 34 & 28 & 20 & 31 & 23 & 553 \\
\hline SUMA & 710 & 1812 & 2369 & 451 & 1613 & 1762 & 3851 & 493 & 1228 & 1031 & 1297 & 952 & 1919 & 948 & 2934 & 528 & 238 \\
\hline
\end{tabular}

Źródło: www.arimr.gov.pl, dane z dnia 10.11.2004 r. 
Z tabeli 3 wynika, iż pozytywnie oceniono 23898 wniosków w skali całego kraju, co stanowiło $76,8 \%$ ogółem złożonych wniosków. W województwie mazowieckim, gdzie złożono największą liczbę wniosków, pozytywną ocenę otrzymało $74,95 \% \mathrm{z}$ nich, a w województwie opolskim (najmniejsza liczba złożonych wniosków) pozytywnie oceniono $75,38 \%$ złożonych wniosków. W województwie podlaskim pozytywnie oceniono 1031 wniosków na 1468 złożonych, co stanowiło 70,23\%. Widzimy więc, iż ,poprawność" wniosków składanych w województwie podlaskim była niższa od średniej krajowej. O ile wnioski składane przez samorządy charakteryzowały się dość wysokim poziomem (96,17\% złożonych wniosków otrzymało pozytywną ocenę), to jakość wniosków składanych przez małe firmy bądź osoby fizyczne mające zamiar rozpocząć taką działalność w ramach Działania 4 jest bardzo niska - z 520 złożonych wniosków tylko 165 otrzymało pozytywną ocenę.

\section{Podsumowanie}

Z przeprowadzonych badań wynika, iż skuteczność aplikowania o pomoc finansową $w$ ramach funduszu SAPARD, rozumiana jako iloraz liczby pozytywie ocenionych wniosków do liczby złożonych wniosków, wynosi $76,8 \%$. Rozpatrując tak rozumianą skuteczność w aspekcie ogólnym (bez analizy poszczególnych działań), można zauważyć, iż:

a) brak jest dodatniej korelacji pomiędzy liczbą złożonych i pozytywnie ocenionych wniosków,

b) nie występuje również ujemna korelacja wartości badanych cech.

$Z$ całą pewnością należy stwierdzić więc, iż skuteczność aplikowania nie zależy od liczby składanych wniosków, co zostało wykazane na przykładzie województwa mazowieckiego (5138 złożonych wniosków, skuteczność $74,95 \%)$ i województwa opolskiego (654 złożone wnioski, skuteczność $75,38 \%)$.

Analizując skuteczność aplikowania w poszczególnych działaniach, można stwierdzić, iż największą skutecznością w ubieganiu o fundusze z programu SAPARD charakteryzują się samorządy terytorialne. Średnia skuteczność dla całego kraju wyniosła $89,65 \%$, przy czym w województwie podlaskim wskaźnik ten wyniósł aż $96,7 \%$, co jest najlepszym wynikiem w skali całego kraju. Najgorszą skutecznością charakteryzują się beneficjencji Działania 4, w którym średnia dla kraju wynosi $49,79 \%$. Na podstawie analizy skuteczności w poszczególnych działaniach można przypuszczać, iż czynnikiem decydującym o skuteczności w pozyskiwaniu środków unijnych jest uprzednio zdobyte doświadczenie, czego przykładem są samorządy terytorialne, które mogą korzystać z funduszy unijnych od $1993 \mathrm{r}$. 


\section{Literatura}

Decyzja Komisji (WE) 2002/593/EC z dnia 2 lipca 2002 r. o przekazaniu Polsce zarządzania programem SAPARD.

Rozporządzenia Rady (WE) nr 1268/99 z dnia 21 czerwca 1999 r. o wsparciu dla działań przedakcesyjnych na rzecz rozwoju rolnictwa i obszarów wiejskich w krajach kandydujących z Europy Środkowej i Wschodniej w okresie przedakcesyjnym.

Rozporządzenie Komisji (WE) nr 2222/2000 z dnia 7 czerwca 2000 r. ustalające szczegółowe zasady finansowe i organizacyjne programu SAPARD.

Rozporządzenie Rady Ministrów z dnia 14.05.2002 r. w sprawie szczegółowego zakresu i kierunków działań oraz sposobów realizacji zadań Agencji Restrukturyzacji i Modernizacji Rolnictwa w zakresie gospodarowania środkami pochodzącymi z funduszy Unii Europejskiej (DzU Nr 102, poz. 928).

\section{The Analysis of Effectiveness of Applying for Financial Resources from SAPARD Program in the Years 2002-2004}

\section{Abstract}

The SAPARD program (Support for Accession Measures for Agriculture and Rural Development) was created in order to conform applicant states to acquis commuinataire in the field of agriculture and rural area development. The support of the Community with the confines of SAPARD program was realized by long-term programs prepared in accordance with guidelines and rules of operational programs used with the confines of structural politics. It's presumed that experience achieved by SAPARD's beneficent would pay dividends in case of EU structural funds using. The authors compared the usage of program SAPARD in the years 2002-2004 in some regions of the country (paying attention to Podlaskie province because of its delay in the infrastructure development and agricultural character). The research shows that the effectiveness of applying for financial resources from SAPARD program (measured by the share of positively considered applications in total amount of turned applications) was about $76.8 \%$. Analyzing the effectiveness of applying in individual actions, it's been stated that local governments are characterized by the highest effectiveness of applying for financial resources from SAPARD program. The average effectiveness in this action on the country scale was $89.65 \%$, when in Podlaskie province it was $96.7 \%$, what was the best result on the country scale. 